\title{
The Relation of Stunting with Immunization Status and the History of Low Birth Weight in the Work Area of Public Health Center at Gilingan
}

\author{
$1^{\text {st }}$ Wahyuni, W \\ Nursing Program Bachelor Degree \\ STIKES 'Aisyiyah Surakarta \\ Indonesia \\ yunyskh@gmail.com \\ $4^{\text {th }}$ Widayati, R. S \\ Midwivery Program in Diploma \\ degree, STIKES 'Aisyiyah Surakarta \\ Indonesia
}

\author{
$2^{\text {nd }}$ Wakhidah, L. N \\ Nursing Program Bachelor Degree \\ STIKES 'Aisyiyah Surakarta \\ Indonesia
}

\author{
$3^{\text {rd }}$ Fatmawati, $\mathrm{S}$ \\ Midwivery Program in Diploma \\ degree, STIKES 'Aisyiyah Surakarta \\ Indonesia
}

\begin{abstract}
In the Asian level, Indonesia has ranked at fourth in the highest prevalence of stunting. Stunting is a condition of failure which in term to grow up for infants due to chronic malnutrition, as the consequence, they are too short for their age. The factors that Immunization is one of the most effective public health interventions to reduce the disease and death levels in society. The low birth weight is that when the infants are born, their weights are less than 2.500 grams. The research is aimed to find out whether there is a relation between immunization status and low birth weight against stunting in work area of Public Health Center at Gilingan. The method is an analytic quantitative research by cross sectional design, the technique of data collection applies purposive sampling, the sample consists of 54 respondents,
\end{abstract}

\section{INTRODUCTION}

Infant is the group of children who aged up to a year or more popular with those who aged under five years old or by using calculation in 12-59 months. The experts classify the age of infant as the development stage of children who are quite susceptible to various diseases, including those caused by excess or deficiency of the type of certain nutrition. [1]

The period of infant is the susceptible group that faces the nutritional deficiency and stunting is included on it. According to The National Team for Accelerating Poverty in 2017, stunting is a failed condition for growing up in term to infants caused by the chronic nutritional deficiency so that they grow up slower and shorter as supposed to be in their age. The nutitional deficiency happens since infants live in the womb and at the early period after they are born, although the stunting condition just appears after the infants are in two years. The stunted and the severely stunted are the infants who have body length based on age $(\mathrm{PB} / \mathrm{U})$ or body high based on age $(\mathrm{TB} / \mathrm{U})$, in and the research instrument is KIA book. The result of univariate analysis shows that the complete immunization status of stunting infants is $64.8 \%$, the history of low birth weight is $66.7 \%$, and the stunting infant in short category is $72.8 \%$. The most of stunting infant have the complete immunization status and the the history of low birth weight. It can be assumed that there is a meaningful relation between immunization status and the history of low birth weight toward stunting in work area of Public Health Center at Gilingan.

Keywords-Stunting, Immunization, Low Birth, Public Health

general, this case is compared to the standard of Multy Growth Reference Study (WHO-MGRS) in2006. While, the definition of stunting, according to Health Ministry (Kemenkes) is the infants who have z-score less than-2SD/ deviation standard (stunted) and less than -3SD (severely stunted) [2].

The case of stunting on the infants needs special attention because it is connected to the risk of intellectual capability drop, productivity, and the risk increase of thefurther degenerative disease (Ida, et al (2006)). Based on the annual reported data of United Nations Children's Fun or UNICEF, it is about 178 millions of children getting stunting, while Indonesia, for Asian level, has ranked at fourth as the highest stunting prevalence. From those data, it shows that India has the stunting prevalence $39 \%$ (48.2 millions of stunting infants), then Pakistan has stunting prevalence $45 \%$ (10 millions of stunting infants), while Nigeria has stunting prevalence $33 \%$ (10,0 millions of stunting infants), next, Indonesia has stunting prevalence 
$36 \%$ (8,8 millions of stunting infants), and Cina is about $9 \%$ (7,4 millions of stunting infants) [3].

In national level, the stunting prevalence has been released by Riskesdas (2018) and the result shows that at 2007 , it is about $36.8 \%$, while at 2013 , it is about $37.2 \%$. Shortly, it describes that at the period 2007 until 2013, there is a significant increase about $0.4 \%$. The highest score of stunting prevalence happens in Central Java Province is about $28.6 \%$ which elaborates the very short category is about $11.0 \%$.

While, in Brebes, its category is about $16.8 \%$. it means that this score exceeds the stunting prevalence in Central Java. The result of Basic Health Research (2018) shows that in 2017, the stunting prevalence is on $36.8 \%$ which consists of the very short category $(18.8 \%)$ and the short category $(18 \%)$. In 2013 , the stunting prevalence is on $37.2 \%$ which describes $18 \%$ is categorized on very short and $19.2 \%$ is categorized on short higher. In 2018, the stunting prevalence is on $30.8 \%$ consists of the very short category $(11.5 \%)$ and the short category $(19.3 \%)$. Overall, those cases show that the stunting prevalence from 2013 until 2018 has been getting down about $6 \%$.

Based on the data above, those phenomenons can affect to the obstacle of the physical growth, mental development, and the status of children health. Stunting on children is the effect of nutritional deficiency during a thousand days of early life.

Several factors are often connected and influence the stunting, including poverty, nutritional status, health, sanitation, and environment. There are five main factors of stunting cause namely; poverty, social and culture, the increase of disease infection, the danger of food and society access towards health service. [4].

Main factor that often influence stunting is economic status. As one of factor which can be the complement of

\section{III.}

immunization on the infant or baby is the profession status of a mother, whether she works or not or being a house wife [5]. The economic status is also connected to the low birth weight or BBLR according to Demelash et. Al 2015 in their research [6]. In the country with low income, BBLR is related to bad environment as consequence creating the influence independently on the children growth. Thus, the economic status has significant influence.

The Health Division of Surakarta observes data every year at once. Based on the data in 2017, it consists of six Public Health Centers with the highest stunting prevalence. In Public Health Centers of Banjarsari, it is about 194 infants of 5.510 infants totally as reported to publics, while the lowest stunting prevalence is in Public Health Center of Laweyan about 32 infants of 3.063 infants totally Based on the result of the introduction research done by interview methed in Public Health Center at Gilingan with twelve mothers who have stunting infants said that the history of incomplete basic immunization and the history of normal birth weight, six motherswho have stunting infants said that they has given the complete basic immunization and the normal birth weight, four mothers who have the stunting infants said that the history of the low birth weight and has got the complete basic immunization. The goal of the research is to find out the relation of stunting with immunization status and the history of low birth weight.

\section{METHOD}

The method is an analytic quantitative research with cross sectional design. On this research, it uses the restropective kohort approach with the sample is about 54 respondents totally.

RESULT

TABLE I. THE RELATION OF IMMUNIZATION STATUS WITH STUNTING IN WORK AREA OF PUBLIC

\begin{tabular}{|c|c|c|c|c|c|c|c|c|}
\hline \multirow{3}{*}{$\begin{array}{c}\text { Status } \\
\text { Imunisasi }\end{array}$} & \multicolumn{4}{|c|}{ Stunting } & \multirow{2}{*}{\multicolumn{2}{|c|}{ Total }} & \multirow{2}{*}{$\mathrm{df}$} & \multirow{2}{*}{$P$ Value } \\
\hline & \multicolumn{2}{|c|}{ Sangat pendek } & \multicolumn{2}{|c|}{ Pendek } & & & & \\
\hline & $\mathrm{f}$ & $\%$ & $\mathrm{f}$ & $\%$ & $\mathrm{f}$ & $\%$ & \multirow{3}{*}{1} & \multirow{3}{*}{0.001} \\
\hline Lengkap & 15 & 42.9 & 20 & 57.1 & 35 & 100 & & \\
\hline Tidak & 0 & 0 & 19 & 100 & 19 & 100 & & \\
\hline Total & 15 & 27.8 & 39 & 72.2 & 54 & 100 & & \\
\hline
\end{tabular}

Based on the result of bivariate analysis on the table I above, it shows that the most respondents has the complete basic immunization status with the stunting infants on short category is 20 respondents $(57.1 \%)$, while the respondents who have the incomplete immunization status with the category of short stunting is 19 respondents (100\%). From the result of chi square analysis, it can be assumed that the significant value 0,001 or less than score of $p$ value 0,05 . Thus, Ho is rejected and $\mathrm{Ha}$ is accepted which meant that there is a meaningful relation among immunization status of infant towards stunting case.

In line with the research conducted by [9] Sarri, R and Livana (2018), they show that the immunization status influences significantly to the children growth, nutritional status and the disease preventive treatment. The complementary of basic immunization on the children is influenced by the attitude owned by the mother and her knowledge. The good The result of this research is appropriate with the analysis above which shows that on the previous research, $90 \%$ respondents had got basic immunization which born. Baby and infant are the group which categorized as susceptible to a disease. If the infants do not get immunization, so the body defence of them will be drop and will be easily injected by disease as well as the incomplete immunization status has the significant relation with stunting on the infant and its immunization status related to stunting issue on infants aged on 24-59 month in Bangkalan. 
In line with the research done by [8] Agus Hendra in 2016 , it shows that the complementary of immunization with stunting is seen that the proportion of infants in getting stunting is about $29,2 \%$ getting the incomplete immunization, while the proportion of infants in the condition of complete immunization is about $89.6 \%$, then the result of statistic test is obtained $\mathrm{p}$ value $=0,040$ $(p<0,05)$ so it can be assumed that there a meaningful relation between immunization status towards stunting cases in Banda Aceh City in 2010.

The result of research done by [4] Farah et al. in 2015 shows the factors influence the stunting case on the infants in village and the city. The complete or incomplete immunization status has the significant relation towards stunting on the children age less than five years old. Thus, the infants who get the complete or incomplete basic immunization has the same opportunity in facing stunting.

Attitude will encourage her to be active and rountine in giving basic immunization for her children as scheduled and provided by the government. If the mother's knowledge is good, it will be important to increase the awareness towards immunization so the goodness of health will be obtained by every infant.

It means the stunting infant's proportion is more often found on the infant who has the history of the incomplete basic immunization compared to the history of the complete basic immunization. In this case, the complete basic immunization may not influence the benefit and effectiveness of immunization feed such as vaccine quality that given is not fulfilling the standard or less good. It means both of infant who has the complete or incomplete basic immunization having the same opportunity to facing stunting. The fulfillment of health service for infants can be measured on the schedule of the complete basic immunization that has been obtained or by looking at immunization status on the infant. In this research, most of infants in Gilingan District have obtained the complete basic immunization and just a few of infants still have the incomplete basic immunization. The infant who has the complete or incomplete immunization status is related to stunting case in the work area of Public Health Center at Gilingan. The infant's immunization status is also a factor of the stunting happens. The complementary of the

Based on the bivariate analysis on the table 2 above, it shows that the most of respondents who have the history of low birth weight on stunting infant in short category are 34 respondents $(94.4 \%)$, while the respondents who have the history of the normal birth weight or not low birth weight with stunting infant in very short category are two respondents $(5.6 \%)$. From the chi square analysis, it can be seen that the significant value $<0,001$ or less than $p$ value 0,05 . Thus Ho is rejected and $\mathrm{Ha}$ is accepted which meant that there is the meaningful relation between the low birth weight of infant toward stunting case in work area of Public Health Center at Gilingan. Odds Ration (OR) value is about 44.200 , it means that the infant with the history of low birth weight has the higher risk in getting stunting 44.200 times than the infants who have the history of the low birth weight.

Basic immunization on the infants in the work area of Public Health Center at Gilingan is influenced by the case of mothers' profession status as worker, official employers so many infants are handled by their grandmother. And for the mothers who have the infant or children aged on 0-59 month, they should give the immunization or vaccine rountinely that ruled on the schedule of health service that has been existed. The support come by family especially mother towards stunting infant is needed to facilitate in giving immunization for dropping the number of the stunting infants in work area of Public Health Center at Gilingan.

TABLE II. THE RELATION OF THE HISTORY OF LOW BIRTH WEIGHT WITH STUNTING IN WORK AREA OF PUBLIC HEALTH CENTER AT GILINGAN

\begin{tabular}{|c|c|c|c|c|c|c|c|c|c|c|c|}
\hline \multirow{3}{*}{$\begin{array}{c}\text { Berat } \\
\text { Badan } \\
\text { Lahir }\end{array}$} & \multicolumn{4}{|c|}{ Stunting } & & & \multirow[b]{2}{*}{$\mathrm{df}$} & \multirow{2}{*}{ P value } & \multirow[b]{2}{*}{ OR } & \multirow[b]{2}{*}{ Upper } & \multirow[b]{2}{*}{ Lower } \\
\hline & \multicolumn{2}{|c|}{ Sangat Pendek } & \multicolumn{2}{|c|}{ Pendek } & \multicolumn{2}{|c|}{ Total } & & & & & \\
\hline & $\mathrm{f}$ & $\%$ & $\mathrm{f}$ & $\%$ & $\mathrm{f}$ & $\%$ & & & & & \\
\hline $\begin{array}{l}\text { Tidak } \\
\text { BBLR }\end{array}$ & 13 & 72.2 & 5 & 27.2 & 18 & 100 & 1 & $<0.001$ & 44.200 & 7.605 & 256.903 \\
\hline BBLR & 2 & 5.6 & 34 & 94.4 & 39 & 100 & & & & & \\
\hline Total & 18 & 27.8 & 36 & 72.2 & 54 & 100 & & & & & \\
\hline
\end{tabular}

The result of research is supported by the [10] research which shows that 22 respondents of the low birth weight infants are 16 respondents $(72.7 \%)$ getting stunting, so it can be concluded that there is a meaningful relation between the low birth weight towards stunting case in Public Health Center at Lima Puluh. The low birth weight can be caused by the lack of nutrition when pregnancy so it effects inta uteri growth retaration, and when infant is born, it is manifested by the low of birth weight. The long term problem caused by the low birthweight is the obstacle of the growth and the development. The low birth weight is believed becoming one of the factors causes stunting.

From the research [11], it can be seen that the multivariate analysis shows that the low birth weight is a dominant factor towards the stunting. This case can be proved by the statistic result p-value 0.047 and the OR value: 5.092 and supported by Nasution Research (2013) which elaborates the low birth weight since on pregnancy has got the retardation of intrauterine growth and it will continue until the further age after born is that getting the slower growth and the development than the infant that 
born normally and it often gets failed reaching the level of growth supposed to be achieved on those age after born. The other research done by [12], the result shows that the history of the low birth weight has the higher risk at twelve times than the infants with the normal birth weight.

There is a relation of the low birth weight towards stunting in Public Health Center at Gilingan. It means that if the number of birth is higher for infants with the low body weight than normal weight or the low birth weight so it will drop the number of birth of infants with the normal body weight. Some of mother at Gilingan district said that when they are pregnant, not too thinking or paying attention to nutritional status on fetus so most of infants born with the history of low birth weight so it affects to those growth, one of them is getting stunting. The support of family is very needed especially from husband when the mother is on pregnant period and the health staffs of those area monitors the mother's health in their work area in order to keep many infants can be born in healthy condition and drop the baby birth with low birth weight which influence the growth of infants in the future, and also decrease the number of stunting cases in work area of Public Health Centers at Gilingan.

\section{CONCLUSION}

There is a relation between the complete immunization status and the history of low birth weight towards stunting. In addition, the pregnant mothers are recommended to pay more attention in fetus health status especially nutritional status on it. For those who have stunting infants or not, they should always rountinely fulfill the provision of vaccines or the complete basic immunization.

\section{ACKNOWLEDGMENT}

Author would like to thank STIKES 'Aisyiyah Surakarta and Puskesmas Gilingan for supporting this research.

Info Datin Kementerian Kesehatan, "Situasi DBD di Indonesia," InfoDATIN. p. p 12, 2016.

[2] K. Desa, P. D. Tertinggal, and K. Sambutan, "Buku Saku Desa dalam Penanganan Stunting," 2018.

[3] UNICEF, Supply Annual Report 2017 Focus: Sustainable Access. 2018.

[4] Aridiyah, F. O., Rohmawati,N., \& Ririanty, M. (2015). Faktor-faktor yang Mempengaruhi Kejadian Stunting pada Anak Balita di Wilayah Pedesaan dan Perkotaan (The Factors Affecting Stunting on Toddlers in Rural and Urban Area)," e-Journal Pustaka Kesehatan. vol. 3, no. 12, pp.1.

[5] Suyatno, D. H., \& Dharmawan, Y. (2017). Hubungan Karakteristik Ibu, Pola Asuh Dan Pemberian Imunisasi Dasar Terhadap Status Gizi Anak Usia 12-24 Bulan (Studi Di Wilayah Kerja Puskesmas Kedungmundu Kota Semarang Tahun 2017). Jurnal. Kesehatan. Masyarakat. vol. 5, no. 4,pp.788800.

[6] Nuryani, N. \& Rahmawati, R. (2017). Kejadian Berat Badan Lahir Rendah di Desa Tinelo Kabupaten Gorontalo dan Faktor yang Memengaruhinya. Jurnal Gizi dan Pangan. vol. 12, no. 1, pp. 49-54.[7] Illahi, R. K., \& Muniroh, L. (2018).

[7] Gambaran Sosio Budaya Gizi Etnik Madura Dan Kejadian Stunting Balita Usia 24-59 Bulan Di Bangkalan. Media Gizi Indonesia. vol. 11, no. 2, pp. 135.

[8] Rahmad, A. H., \& Miko, A. (2016). Kajian Stunting pada Anak Balita Berdasarkan Pola Asuh dan Pendapatan Keluarga di Kota Banda Aceh. Jurnal Kesmas Indonesia. vol. 8 , no. 2 , pp. $63-79$.
Sarri, R. K., \& Livana, P. (2018). Description of Knowledge and Attitude of Women in Rendering Abstract. Jurnal Keperawatan. vol. 10, no. 1, pp. 75-82.

[10] Fitri, L. (2018). Hubungan Bblr Dan Asi Ekslusif Dengan Kejadian Stunting Di Puskesmas Lima Puluh Pekanbaru. Jurnal Endur. vol. 3, no. 1, pp. 131.

[11] Manggala, A. K., et al. (2018). Risk Factors of Stunting in Children Aged 24-59 months. Paediatr. Indonesia. vol. 58, no. 5, pp. 205-212.

[12] Lestari, E. D., Hasanah, F., \& Nugroho, N. A. (2018). Correlation between Non- Exclusive Breastfeeding and Low Birth Weight to Stunting in Children. Paediatr. Indones., vol. 